\title{
ROLE OF MIDDLE CEREBRAL ARTERY DOPPLER AND AMNIOTIC FLUID INDEX IN PREDICTING PERINATAL OUTCOME IN POSTDATED PREGNANCIES
}

\author{
By
Ahmed Ali El-Sebahy, Mohammed Taher Ismail, Mohammed Salah El- Din Hassanien and Ahmed Shaaban Mohammed \\ Department of Obstetrics \& Gynecology, Faculty of Medicine, Al-Azhar University \\ E-mail: drrahmedelsebahy@ gmail.com
}

\begin{abstract}
Background: Post-date pregnancy carries many fold problems for both pregnancy and fetal outcome. Abnormal middle cerebral artery Dopplers are strongly associated with preterm delivery and antenatal steroid administration.

Objective: To identify the relationship between middle cerebral artery Doppler, Amniotic fluid index and perinatal outcomes in postdated pregnancies.

Patients and Methods: This study was performed on 50 pregnant women whose gestational age was 40-42 weeks' gestation attending the antenatal clinic of Zefta General Hospital. The study was done during the period between December 2017 and August 2019.Inclusion criteria included singleton living fetuses with vertex presentation in postdated pregnancies $(40-42)$ week gestation. Exclusion criteria included cases with premature rupture of membranes, antepartum hemorrhage and maternal medical disorders as hypertension, diabetes mellitus, hepatic, cardiac, renal or anemia with pregnancy, patients with uterine scar. All patients were subjected to detailed history taking, physical examination and routine investigations including complete blood picture, Rh typing, fasting blood sugar, liver functions, kidney functions and urine analysis. Ultrasound and Doppler study were done twice weekly till the onset of labor or termination of pregnancy in order to assess GA, estimated fetal weight (EFW), placental site and grading, amniotic fluid volume (AFV) (oligohydramnios was diagnosed if the largest vertical pocket less than $2 \mathrm{~cm}$ ), Doppler study of the MCA. The study population was divided into two groups based on the presence or absence of adverse perinatal outcome.
\end{abstract}

Results: Expected fetal weight (EFW), resistive Index of middle cerebral artery (MCA) and resistive Index of umbilical artery (UA) were not significantly predicting perinatal outcome of postdated pregnancies among the studied pregnant women. Amniotic fluid index (AFI) and biophysical profile (BPP) were significant predictors for perinatal outcome of postdated pregnancies.

Conclusion: Resistive Index of (MCA) was not significant predictor for perinatal outcome of postdated pregnancies. Amniotic fluid index was significant predictor for perinatal outcome of postdated pregnancies.

Keywords: Middle cerebral artery Doppler - Amniotic fluid index - Predictors - postdated pregnancies.

\section{INTRODUCTION}

Post- term pregnancy is a pregnancy that extends to 42 weeks of gestation or beyond. Fetal, neonatal and maternal complications associated with this condition have always been underestimated. It is not well understood why some women become post term although in obesity, hormonal and genetic 
AHMED ALI EL-SEBAHY et al.,

factors have been implicated (Galal et al., 2012). Overall incidence varies between 4 and 19\% (Chauhan and Malik, 2020).

Post-term pregnancy is associated with an increased risk of adverse fetal outcome (Liston et al., 2018).

The major causes of fetal death include gestational hypertension, prolonged labor with cephalopelvic disproportion and malformations (Cunninghamand Leveno, 2010).

A safe limit for continuation of pregnancy beyond expected date of delivery cannot be established. Some suggested that risk of post maturity starts at 40 weeks (Maged et al., 2014). American College of Obstetricians and Gynecologists (ACOG) suggested that initiation of fetal surveillance at 41 weeks is a reasonable option (Lindqvist et al., 2014).

Fetal Doppler velocimetry has been used as a good parameter for assessment of fetal well-being. A large experience with this technique has been reported with respect to the prediction of the fetus at risk of developing intrauterine growth restriction (IUGR), antepartum and intrapartum fetal asphyxia, and neonatal morbidity. Several studies indicated that Doppler indices may be powerful predictors of adverse perinatal outcome in complicated pregnancies (Maged et al., 2014).

Doppler velocimetry is useful to prognosticate restricted fetal development in normal pregnancies (Nomura et al., 2015). Abnormal MCA Dopplers are strongly associated with preterm delivery, antenatal steroid administration, and neonatal intensive care unit stay (Vahanian et al., 2016).

The aim of this work was to identify the relationship between middle cerebral artery Doppler, amniotic fluid index and perinatal outcomes in postdated pregnancies.

\section{PATIENTS AND METHODS}

This prospective observational study was done on 50 pregnant women whose gestational age (GA) was 40-42 weeks' gestation attending the antenatal clinic of Zefta General Hospital. The study was done during the period between December 2017 and August 2019.

The study was approved by local ethics committee, and an informed written consent was obtained from every participant.

Inclusion criteria included singleton living fetuses with vertex presentation in postdated pregnancies40 - 42 weeks gestation. An accurate estimation of GA was calculated from the first day of regular last menstrual cycle and confirmed or modified by an early ultrasound examination before 20 weeks gestation.

Exclusion criteria included cases with premature rupture of membranes, antepartum hemorrhage and maternal medical disorders as hypertension, diabetes mellitus, hepatic, cardiac, renal or anemia with pregnancy. Patients with uterine scar.

All patients were subjected to detailed history taking, physical examination and routine investigations including complete blood picture, Rh typing, fasting blood sugar, liver functions, kidney functions and urine analysis. 
Ultrasound and Doppler study were done twice weekly till the onset of labor or termination of pregnancy in order to assess GA, estimated fetal weight (EFW), placental site and grading, amniotic fluid volume (AFV) (oligohydramnios was diagnosed if the largest vertical pocket less than $2 \mathrm{~cm}$ ), Doppler study of the MCA.

Spontaneous vaginal delivery was awaited, but induction of delivery was done if there was oligohydraminos, BPP is less than 6 or if the period of gestation extended beyond 42 weeks. With a Bishop score more than7, labor was induced.

The study population was divided into two groups based on the presence or absence of adverse perinatal outcome. Adverse perinatal outcome was defined as the presence of one or more of the following: Cesarean delivery for fetal distress, Apgar scoreless than 7 at 1 and 5 min, meconium aspiration syndrome (MAS) or neonatal intensive care unit admission.

\section{Statistical methods:}

The collected data were organized, tabulated and statistically analyzed using SPSS software (Statistical Package for the Social Sciences, version 21, SPSS Inc. Chicago, IL, USA). For quantitative data, the range, mean, median and standard deviation were calculated. For qualitative data, which described a categorical set of data by frequency, percentage or proportion of each category, comparison between two groups and more was done using Chi-square test $(\chi 2)$. For comparison between means of two groups of parametric data of independent samples, student t-test was used. For comparison between more than two means of parametric data, $F$ value of ANOVA test was calculated. Binary logistic regression analysis was done, where Logistic regression coefficients (B) are calculated and used to estimate Odds ratios (EXP (B)) for different variables and parameters as independent predictors for prognosis to perinatal outcome as good or adverse perinatal outcome among pregnant women (40-42 weeks gestation). The Receiver Operating Characteristic (ROC) curve was done, to detect the area under the curve which reflects the accuracy of different parameters as diagnostic to perinatal outcome as good or adverse perinatal outcome among pregnant women (40-42 weeks gestation). Significance was adopted at $\mathrm{p}<0.05$ for interpretation of results of tests of significance.

\section{RESULTS}

Age ranged among good perinatal outcome group (group 1) of 19 years and 35 years with mean $26.41 \pm 4.25$ while ranged among adverse perinatal outcome group (group 2) between 18 years and 42 years with mean $28.11 \pm 6.85$. The body weight ranged among group (1) between55 $\mathrm{kg}$ and $124 \mathrm{~kg}$ with mean $82.59 \pm 15.87$ while ranged among group (2) between $58 \mathrm{~kg}$ and $135 \mathrm{~kg}$ with mean $82.72 \pm 18.05$. The gestational age ranged among group (1) between 40 week and 42 week with mean $40.72 \pm 0.81$ while ranged among group (2) between 40 week and 42 
week with mean $40.72 \pm 0.83$. regarding parity there were $7 \mathrm{P} 1$ cases $(70 \%), 8 \mathrm{P} 2$ cases $(72.7 \%), 4 \mathrm{P} 3$ cases $(57.1 \%)$, no P4 cases and 13 PG cases (65\%) among group 1 while there were $3 \mathrm{P} 1$ cases (30\%), 3 P2 cases $(27.3 \%), 3$ P3 cases (42.9\%), 2 P4 cases (100\%) and 7 PG cases (35\%) among group 2. Regarding Placental site there were 11 cases $(78.6 \%)$ with anterior placenta, 13 cases $(50 \%)$ with fundal placenta and 8 cases $(80 \%)$ with posterior placenta among group 1 while there were 3 cases $(21.4 \%)$ with anterior placenta, 13 cases $(50 \%)$ with fundal placenta and 2 cases $(20 \%)$ with posterior placenta among group 2 . Regarding Placental grade there was no cases with grade II placenta, 24 cases $(60 \%)$ with grade III placenta and 8 cases $(88.9 \%)$ with grade IV placenta among group 1 while there was 1 case $(100 \%)$ with grade II placenta, 16 cases $(40 \%)$ with grade III placenta and 1 case $(11.1 \%)$ with grade IV placenta among group 2 (Table 1).

Table (1): Perinatal outcome among the studied pregnant women (40-42 weeks gestation) in relation to age (years), gestational age (weeks), body weight $(\mathrm{kg})$, parityand placental site and grade $(n=50)$

\begin{tabular}{|c|c|c|c|c|c|}
\hline $\begin{array}{r}\text { Perinatal outcome } \\
\text { among the studied } \\
\text { women with } \\
40-42 \text { weeks } \\
\text { gestation }\end{array}$ & \multicolumn{2}{|c|}{$\begin{array}{c}\text { Good } \\
\text { perinatal } \\
\text { outcome } \\
\text { (group 1) } \\
(n=32)\end{array}$} & \multicolumn{2}{|c|}{$\begin{array}{c}\text { Adverse } \\
\text { perinatal } \\
\text { outcome } \\
\text { (group 2) } \\
(n=18)\end{array}$} & $\mathbf{P}$ \\
\hline \multicolumn{6}{|l|}{$\begin{array}{l}\text { Variables } \\
\text { Age years }\end{array}$} \\
\hline $\begin{array}{l}\text { Range } \\
\text { Mean } \pm \text { SD }\end{array}$ & \multicolumn{2}{|c|}{$\begin{array}{c}19-35 \\
26.41 \pm 4.25\end{array}$} & \multicolumn{2}{|c|}{$\begin{array}{c}18-42 \\
28.11 \pm 6.85\end{array}$} & $>0.05$ \\
\hline \multicolumn{6}{|l|}{ Body weight (kg) } \\
\hline $\begin{array}{l}\text { Range } \\
\text { Mean } \pm \text { SD }\end{array}$ & \multicolumn{2}{|c|}{$\begin{array}{c}55-124 \\
82.59 \pm 15.87\end{array}$} & \multicolumn{2}{|c|}{$\begin{array}{c}58-135 \\
82.72 \pm 18.05\end{array}$} & $>0.05$ \\
\hline \multicolumn{6}{|l|}{ Gestational age (weeks) } \\
\hline $\begin{array}{l}\text { Range } \\
\text { Mean } \pm \text { SD }\end{array}$ & \multicolumn{2}{|c|}{$\begin{array}{c}40-42 \\
40.72 \pm 0.81\end{array}$} & \multicolumn{2}{|c|}{$\begin{array}{c}40-42 \\
40.72 \pm 0.83 \\
\end{array}$} & $>0.05$ \\
\hline & $\mathrm{n}$ & $\%$ & $\mathrm{n}$ & $\%$ & \\
\hline $\begin{array}{l}\text { Parity } \\
1 \\
2 \\
3 \\
4 \\
\text { (Primigravida) }\end{array}$ & $\begin{array}{c}7 \\
8 \\
4 \\
0 \\
13\end{array}$ & $\begin{array}{c}70.0 \\
72.7 \\
57.1 \\
0 \\
65.0\end{array}$ & $\begin{array}{l}3 \\
3 \\
3 \\
2 \\
7\end{array}$ & $\begin{array}{c}30.0 \\
27.3 \\
42.9 \\
100 \\
35.0\end{array}$ & $>0.05$ \\
\hline $\begin{array}{l}\text { Placental site: } \\
\text { Anterior } \\
\text { Fundal } \\
\text { Posterior }\end{array}$ & $\begin{array}{c}11 \\
13 \\
8\end{array}$ & $\begin{array}{l}78.6 \\
50.0 \\
80.0\end{array}$ & $\begin{array}{c}3 \\
13 \\
2\end{array}$ & $\begin{array}{l}21.4 \\
50.0 \\
20.0\end{array}$ & $>0.05$ \\
\hline $\begin{array}{l}\text { Placental grade: } \\
\text { II } \\
\text { III } \\
\text { IV }\end{array}$ & $\begin{array}{c}0 \\
24 \\
8\end{array}$ & $\begin{array}{c}0 \\
60.0 \\
88.9\end{array}$ & $\begin{array}{c}1 \\
16 \\
1\end{array}$ & $\begin{array}{c}100 \\
40.0 \\
11.1\end{array}$ & $>0.05$ \\
\hline
\end{tabular}


At $1^{\text {st }}$ visit, resistive index of middle cerebral artery among group 1 ranged between 0.50 and 0.83 with mean $0.74 \pm 0.08$ and median 0.76 . At $2^{\text {nd }}$ visit, resistive index of middle cerebral artery ranged between 0.55 and 0.89 with mean $0.73 \pm 0.09$ and median 0.75 . At $3^{\text {rd }}$ visit, resistive index of middle cerebral artery ranged between 0.45 and 0.83 with mean $0.67 \pm 0.13$ and median 0.72 . At $1^{\text {st }}$ visit, resistive index of middle cerebral artery among group 2 ranged between 0.59 and 0.88 with mean $0.73 \pm 0.09$ and median 0.74 . At $2^{\text {nd }}$ visit, resistive index of middle cerebral artery ranged between 0.56 and 0.79 with mean $0.67 \pm 0.09$ and median 0.71 . At $3^{\text {rd }}$ visit, resistive index of middle cerebral artery ranged between 0.45 and 0.82 with mean $0.63 \pm 0.12$ and median 0.62 (Table 2).

Table (2): Perinatal outcome of the studied pregnant women (40-42 weeks gestation) in relation to the Resistive Index (RI) of middle cerebral artery (MCA) $(\mathbf{n}=\mathbf{5 0})$

\begin{tabular}{|c|c|c|c|c|}
\hline $\begin{array}{l}\text { Perinatal outcome of the } \\
\text { studied pregnant women } \\
\text { (40-42 weeksstation) }\end{array}$ & $\begin{array}{c}\text { Good } \\
\text { perinatal } \\
\text { outcome } \\
\text { (group 1) } \\
(\mathbf{n}=32)\end{array}$ & $\begin{array}{c}\text { Adverse } \\
\text { perinatal } \\
\text { outcome } \\
\text { (group 2) } \\
(\mathrm{n}=18)\end{array}$ & $\begin{array}{c}\text { Total } \\
(\mathbf{n}=\mathbf{5 0})\end{array}$ & $\mathbf{P}$ \\
\hline $1^{\text {st }}$ & $(n=32)$ & $(\mathrm{n}=18)$ & $(\mathrm{n}=50)$ & \\
\hline Range & $0.50-0.83$ & $0.59-0.88$ & $0.50-0.88$ & \multirow{3}{*}{$>0.05$} \\
\hline Mean \pm SD & $0.74 \pm 0.08$ & $0.73 \pm 0.09$ & $0.74 \pm 0.08$ & \\
\hline Median & 0.76 & 0.74 & 0.76 & \\
\hline $2^{\text {nd }}$ & $(n=22)$ & $(n=13)$ & $(n=35)$ & \\
\hline Range & $0.55-0.89$ & $0.56-0.79$ & $0.55-0.89$ & \multirow{3}{*}{$>0.05$} \\
\hline Mean \pm SD & $0.73 \pm 0.09$ & $0.67 \pm 0.09$ & $0.71 \pm 0.09$ & \\
\hline Median & 0.75 & 0.71 & 0.74 & \\
\hline $3^{\text {rd }}$ & $(\mathrm{n}=17)$ & $(n=9)$ & $(n=26)$ & \\
\hline Range & $0.45-0.83$ & $0.45-0.82$ & $0.45-0.83$ & \multirow{3}{*}{$>0.05$} \\
\hline Mean \pm SD & $0.67 \pm 0.13$ & $0.63 \pm 0.12$ & $0.66 \pm 0.12$ & \\
\hline Median & 0.72 & 0.62 & 0.69 & \\
\hline F value & 4.588 & 8.000 & 11.308 & \\
\hline $\mathbf{P}$ & 0.101 & 0.018 & 0.004 & \\
\hline
\end{tabular}

At $1^{\text {st }}$ visit, biophysical profile among group 1 ranged between 8 and 10 with mean $9.94 \pm 0.35$ and median 10 . At $2^{\text {nd }}$ visit, biophysical profile ranged between 10 with mean $10.00 \pm 0.00$ and median 10 . At $3^{\text {rd }}$ visit, biophysical profile ranged between 8 and 10 with mean $9.76 \pm 0.66$ and median 10 . At $1^{\text {st }}$ visit, biophysical profile among group 2 ranged between 8 and 10 with mean $9.89 \pm 0.47$ and median 10 . At $2^{\text {nd }}$ visit, biophysical profile ranged between 8 and 10 with mean $9.69 \pm 0.75$ and median 10 . At $3^{\text {rd }}$ visit, biophysical profile ranged between 8 and 10 with mean $8.67 \pm 1.00$ and median 8. There was statistical significance between the 2 groups regarding $3^{\text {rd }}$ visit (Table 3). 
AHMED ALI EL-SEBAHY et al.,

Table (3): Perinatal outcome of the studied pregnant women (40-42 weeks gestation) in relation to the Biophysical profile $(B P P)(n=50)$

\begin{tabular}{|c|c|c|c|c|}
\hline $\begin{array}{l}\text { Perinatal outcome of the } \\
\text { studied pregnant women } \\
\text { (40-42 weekgestation) }\end{array}$ & $\begin{array}{c}\text { Good } \\
\text { perinatal } \\
\text { outcome } \\
\text { (group 1) } \\
(\mathbf{n}=32)\end{array}$ & $\begin{array}{c}\text { Adverse } \\
\text { perinatal } \\
\text { outcome } \\
\text { (group 2) } \\
(n=18)\end{array}$ & $\begin{array}{c}\text { Total } \\
(\mathbf{n}=\mathbf{5 0})\end{array}$ & $\mathbf{P}$ \\
\hline $1^{\text {st }}$ & $(n=32)$ & $(n=18)$ & $(n=50)$ & \\
\hline Range & $8.00-10.00$ & $8.00-10.00$ & $8.00-10.00$ & \\
\hline Mean \pm SD & $9.94 \pm 0.35$ & $9.89 \pm 0.47$ & $9.92 \pm 0.39$ & \\
\hline Median & 10.00 & 10.00 & 10.00 & $>0.05$ \\
\hline $2^{\text {nd }}$ & $(n=22)$ & $(n=13)$ & $(n=35)$ & \\
\hline Range & 10.00 & $8.00-10.00$ & $8.00-10.00$ & \\
\hline Mean \pm SD & $10.00 \pm 0.00$ & $9.69 \pm 0.75$ & $9.88 \pm 0.47$ & \\
\hline Median & 10.00 & 10.00 & 10.00 & $>0.05$ \\
\hline $3^{\text {rd }}$ & $(\mathrm{n}=17)$ & $(n=9)$ & $(n=26)$ & \\
\hline Range & $8.00-10.00$ & $8.00-10.00$ & $8.00-10.00$ & \\
\hline Mean \pm SD & $9.76 \pm 0.66$ & $8.67 \pm 1.00$ & $9.38 \pm 0.94$ & $<$ \\
\hline Median & 10.00 & 8.00 & 10.00 & 0.001 \\
\hline $\begin{array}{l}\text { F value } \\
P\end{array}$ & $\begin{array}{l}4.000 \\
0.135\end{array}$ & $\begin{array}{c}\mathbf{1 2 . 0 0 0} \\
0.002\end{array}$ & $\begin{array}{c}\mathbf{1 6 . 0 0 0} \\
0.001\end{array}$ & \\
\hline
\end{tabular}

Expected fetal weight (EFW), Resistive Index of (MCA) and Resistive Index of (UA) were not significant predictors for perinatal outcome among the studied pregnant women (40-42 weeks gestation) While Amniotic fluid index

(AFI) and Biophysical profile (BPP) were significant predictors for perinatal outcome among the studied pregnant women (40-42 weeks gestation) $(\mathrm{P}=0.039$ and 0.009 respectively) (Table 4). 
Table (4): Regression analysis of different assessed parameters during last weeks before delivery as predictors for perinatal outcome (adverse vs good outcome) among the studied pregnant women (40-42 weeks of gestation)

\begin{tabular}{|c|c|c|c|c|c|c|}
\hline \multirow{2}{*}{ Parameters } & \multirow[t]{2}{*}{ B } & \multirow[t]{2}{*}{ SE } & \multirow[t]{2}{*}{$\begin{array}{l}\text { Sig. (P } \\
\text { value) }\end{array}$} & \multirow[t]{2}{*}{ EX (B) } & \multicolumn{2}{|c|}{$\begin{array}{c}\text { Confidence interval } \\
\text { (CI) }\end{array}$} \\
\hline & & & & & $\begin{array}{c}\text { Lower } \\
\text { limit }\end{array}$ & $\begin{array}{l}\text { Upper } \\
\text { limit }\end{array}$ \\
\hline \multicolumn{7}{|c|}{ Expected fetal weight (EFW) } \\
\hline $\mathbf{1}^{\text {st }}$ & 0.001 & 0.005 & 0.837 & 1.001 & 0.990 & 1.013 \\
\hline $2^{\text {nd }}$ & 0.005 & 0.012 & 0.656 & 0.995 & 0.971 & 1.019 \\
\hline $3^{\text {rd }}$ & 0.006 & 0.010 & 0.553 & 1.005 & 0.987 & 1.025 \\
\hline \multicolumn{7}{|c|}{ Amniotic fluid index (AFI) } \\
\hline $\mathbf{1}^{\text {st }}$ & 0.254 & 0.123 & 0.039 & 0.776 & 0.609 & 0.988 \\
\hline $2^{\text {nd }}$ & 0.356 & 0.189 & 0.060 & 0.701 & 0.483 & 1.016 \\
\hline $3^{\text {rd }}$ & 0.329 & 0.202 & 0.104 & 0.720 & 0.485 & 1.070 \\
\hline \multicolumn{7}{|c|}{ Resistive Index (RI) (MCA) } \\
\hline $\mathbf{1}^{\text {st }}$ & 0.715 & 3.590 & 0.842 & 0.489 & 0.060 & 0.954 \\
\hline $2^{\text {nd }}$ & 7.324 & 4.116 & 0.075 & 0.001 & 0.000 & 2.104 \\
\hline $3^{\text {rd }}$ & 2.877 & 3.343 & 0.402 & 0.056 & 0.000 & 7.410 \\
\hline \multicolumn{7}{|c|}{ Resistive Index (RI) (UA) } \\
\hline $1^{\text {st }}$ & 0.300 & 2.535 & 0.906 & 0.741 & 0.005 & $\begin{array}{c}106.43 \\
8 \\
\end{array}$ \\
\hline $2^{\text {nd }}$ & 3.340 & 3.619 & 0.356 & 28.229 & 0.023 & 71.422 \\
\hline $3^{\text {rd }}$ & 4.803 & 4.396 & 0.275 & 12.835 & 0.022 & 67.371 \\
\hline \multicolumn{7}{|c|}{ Biophysical profile (BPP) } \\
\hline $1^{\text {st }}$ & 0.300 & 0.723 & 0.878 & 0.741 & 0.180 & 3.055 \\
\hline $2^{\text {nd }}$ & 0.215 & 0.542 & 0.641 & 0.425 & 0.002 & 4.202 \\
\hline $3^{\text {rd }}$ & 1.354 & 0.516 & 0.009 & 0.258 & 0.094 & 0.710 \\
\hline
\end{tabular}

$\mathrm{B}=$ Logistic Regression Coefficient

$\mathrm{SE}=$ Standard Error of $\mathrm{B}$

$\mathrm{P}=$ Significance level

$\operatorname{Exp}(\mathrm{B})=$ Estimated Odds Ratio

\section{DISCUSSION}

Post-date pregnancy carries many fold problems for both pregnancy and fetal outcome namely; oligohydramnios which may be indicator of poor placental reserve, macrosomia with shoulder dystocia with the possibility of obstructed labor and fetal distress during labor. Ultimately there will be increase in both perinatal morbidity and mortality (Abd ElHak and Abd EL-Razek, 2011).

Although prolonged pregnancy is associated with increased perinatal morbidity and mortality rates. An ideal method giving accurate information about the condition of the fetus in prolonged pregnancies has not been defined yet (Sayan et al., 2014).

In our study, fetal weight ranged of $2959 \mathrm{gm}$ and $4150 \mathrm{~g}$ with mean $3430.00 \pm 358.14$ and median 3400 which is close to results by (Abd elhak and Abd EL-Razek, 2011) which revealed that fetal weight ranged of $3000 \mathrm{~g}$ and $4400 \mathrm{~g}$ with mean of 3535.8 . 
In our study, aminotic fluid index ranged of 2.00 and 16.00 with mean $9.84 \pm 2.87$ which is quite similar to a study conducted by (EL-Gharib and El-Bohoty, 2020) which revealed that AFI from 4 to 12 with an average of 7.6.

In our study, regarding mode of delivery, 38 cases $(76 \%)$ with vaginal delivery while 12 cases (24\%) with cesarean section. A study by (Monem et al., 2016) which is different to our which revealed that 24 cases $(48 \%)$ with vaginal delivery while 26 cases $(52 \%)$ with cesarean section.

In our study, regarding NICU admission, 40 infants $(80 \%)$ didn't need NICU admission but 10 infants (20\%) needed NICU admission which is quite similar to results by (Monem et al., 2016) which revealed that 41 infants $(82 \%)$ didn't need NICU admission but 9 infants (18\%) needed NICU admission.

In our study, resistive index of middle cerebral artery among good perinatal outcome (group 1) ranged of 0.50 and 0.83 with mean $0.74 \pm 0.08$ and median 0.76. Resistive index of middle cerebral artery among adverse perinatal outcome (group 2) ranged of 0.59 and 0.88 with mean $0.73 \pm 0.09$ and median 0.74 while study by (Sayan et al., 2014) showed quite similar results, resistive index of middle cerebral artery among normal results group ranged of 0.64 and 0.87 with median 0.76. Resistive index of middle cerebral artery among poor results group ranged of 0.41 and 0.79 with median 0.69 . A study by (Monem et al., 2016) showed such similar results; mean of resistive index of middle cerebral artery among no adverse neonatal outcomes group was $0.74 \pm 0.06$ while mean of resistive index of middle cerebral artery among adverse neonatal outcomes group was $0.68 \pm 0.07$.

In our study, resistive index of umbilical artery among group 1 ranged of 0.40 and 0.82 with mean $0.57 \pm 0.13$ and median 0.55 . Resistive index of umbilical artery among group 2 ranged of 0.41 and 0.72 with mean $0.57 \pm 0.10$ and median 0.58 while study by (Sayan et al., 2014) showed quite similar results, resistive index of umbilical artery among normal results group ranged of 0.45 and 0.75 with median 0.60. Resistive index of umbilical artery among poor results group ranged of 0.47 and 0.95 with median 0.68 .

Our study found that AFI is statistically significant in prediction the perinatal outcome of postdated pregnancies. In contrast to that, study by (Monem et al., 2016) found that AFI is considered non-significant predicator in predicting the perinatal outcome of postdated pregnancies.

Our study found that resistive index of middle cerebral artery is considered nonsignificant predicator in predicting the perinatal outcome of postdated pregnancies. In contrast to our study, (Monem et al., 2016) found that middle cerebral artery (MCA) PI had a fair predictive value in predicting the perinatal outcome of postdated pregnancies.

\section{CONCLUSION}

Expected fetal weight (EFW), Resistive Index of (MCA) and Resistive Index of (UA) were not significant predictors for perinatal outcome of postdated pregnancies among the studied pregnant women. Amniotic fluid index (AFI) and biophysical profile (BPP) were significant predictors for perinatal 
outcome of postdated pregnancies among the studied pregnant women.

\section{REFERENCES}

1. Abdelhak AM. and Abd El-Razek AA. (2011): Fetal Middle Cerebral and Umbilical Arteries Doppler Velocimetry and Amniotic Fluid Volume in the Surveillance of Post term Pregnancy. Med. J. Cairo Univ., 79(2): 107-111.

2. Chauhan MB and Malik R. (2020): Post term Pregnancy. In: Labour Room Emergencies. Pbl. Springer, Singapore. pp. 173-181.

3. Cunningham FG and Leveno KJ. (2010): Post-term pregnancy. In: Cunningham FG, Williams JW, eds. William's obstetrics. 23rd ed. Pbl. New York (NY): McGraw-Hill, Chapter 37:535-45.

4. EL-Gharib, MN and El-Bohoty SB. (2020): Lack of Importance of Studying Middle Cerebral Artery Doppler and Amniotic Fluid Index in Prediction of Perinatal Outcome of Prolonged Pregnancies. J Nurs Midwifery, 1(1), 005-008.

5. Galal M, Symonds I, Murray H, Petraglia F and Smith R. (2012): Post term pregnancy. Facts, views \& vision in ObGyn, 4(3): pp.175- 187.

6. Lindqvist PG, Pettersson, K, Morén A, Kublickas $M$ and Nordström $L$. (2014): Routine ultrasound examination at 41 weeks of gestation and risk of postterm severe adverse fetal outcome: a retrospective evaluation of two units, within the same hospital, with different guidelines. BJOG, International Journal of Obstetrics \&Gynaecology, 121(9): 1108-1116.
7. Liston R, Sawchuck D and Young D. (2018): No. 197b-fetal health surveillance: intrapartum consensus guideline. Pbl. Journal of Obstetrics and Gynaecology Canada, 40(4): e298-e322.

8. Maged AM, Abdelhafez A, Mostafa WA and Elsherbiny W. (2014): Fetal middle cerebral and umbilical artery Doppler after 40 weeks gestational age. The Journal of Maternal-Fetal \& Neonatal Medicine, 27(18): 1880-1885.

9. Monem MA, Nazeer AE, AbdElhamed AE and Hassan AB. (2016): Doppler Velocimetry of the fetal middle cerebral artery, umbilical and uterine arteries in the prediction of prolonged pregnancy and their effect on neonatal outcome. Al-Azhar Medical Journal, 45(4): 735-752.

10. Nomura RY, Niigaki JI, Horigome FT, Francisco RV and Zugaib M. (2013): Doppler velocimetry of the fetal middle cerebral artery and other parameters of fetal well-being in neonatal survival during pregnancies with placental insufficiency. Revista da AssociaçãoMédicaBrasileira, 59(4): 392399.

11. Sayan K, Sayan CD and Kokanalı M. K. (2014): The Relationship between Doppler Parameters and Perinatal Outcomes in Postterm Pregnancies. Journal of TurgutOzal Medical Center, 21(4): 264-269.

12. Vahanian S, Kinzler WL, Chen A, Saleh I, Chavez $M$ and Vintzileos AM. (2016): 745: Fetal surveillance using middle cerebral artery (MCA) Dopplers in pregnancies complicated by diabetes. Pbl. American Journal of Obstetrics \& Gynecology, 214(1): S390-S391. 
دوردوبلر الشريان الدماغي الأوسط ومؤشر السائل الامنيوسي في التنبوء بالفترة المحيطة بالو لادة في حالات الات الحمل المطول أحمد على عبد الخالق السبحى، محمد طاهر اسماعيل، محمد صلاح الاين حسانين،

\section{أحمد شعبان محمد}

قسم النساء والتوليد، كلية الطب، جامعة الأزهر

E-mail: drrahmedelsebahy@gmail.com

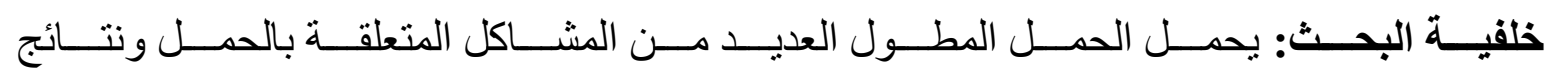

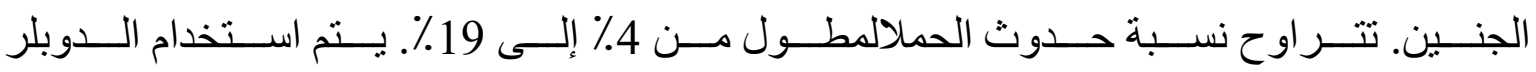

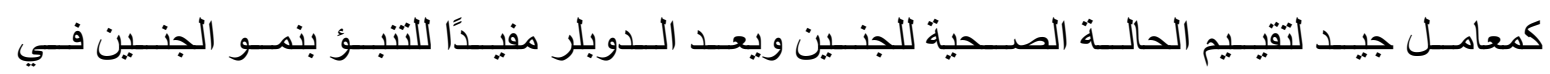

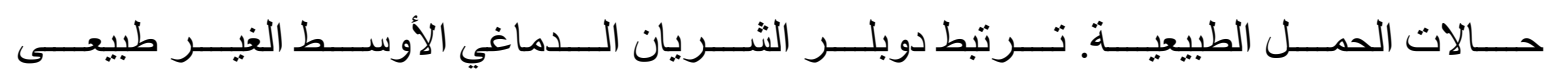
ارتباطًا وثثقًا بالو لادة المبكرة و اعطاء الستيرويد قبل الولادة.

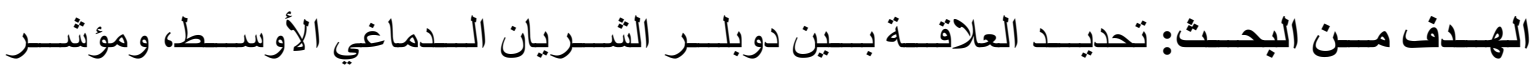

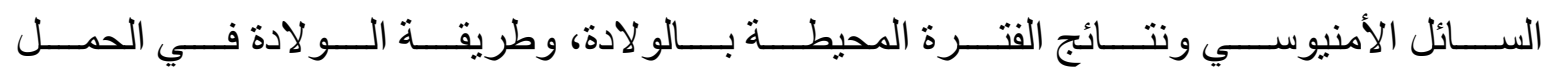

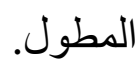

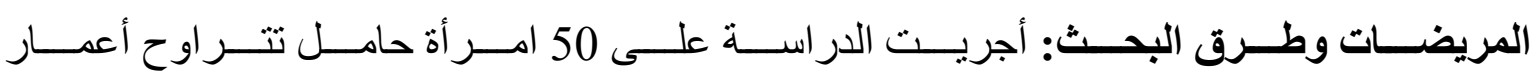

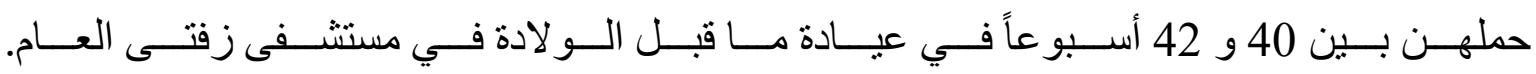

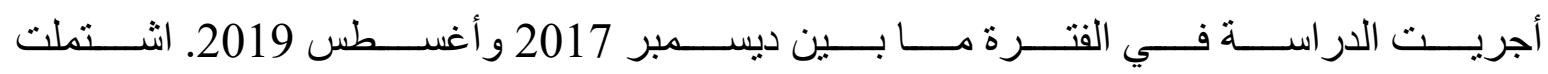

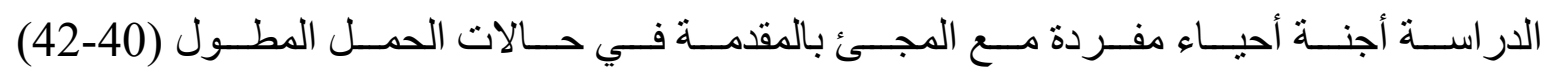

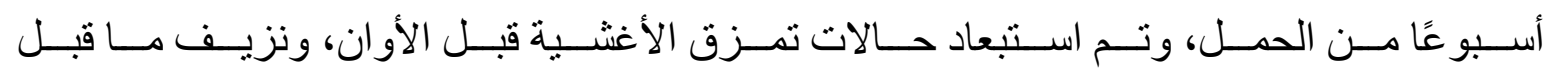

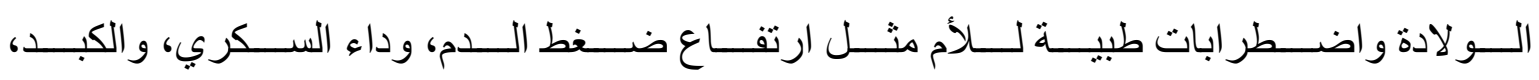

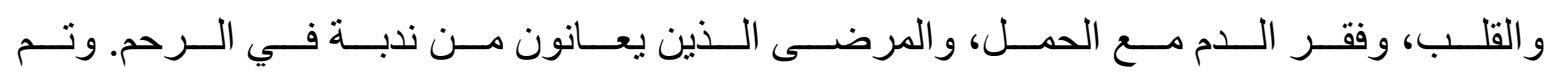

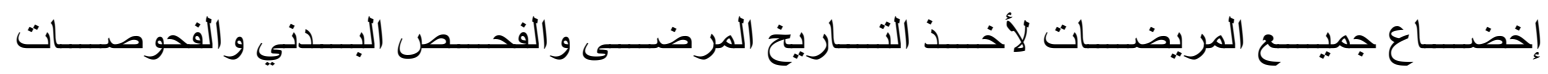

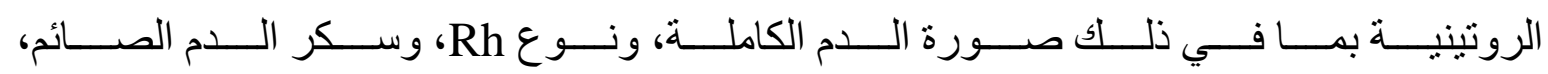

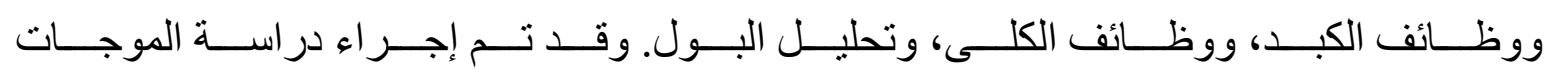

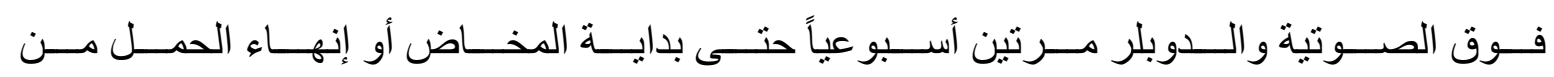

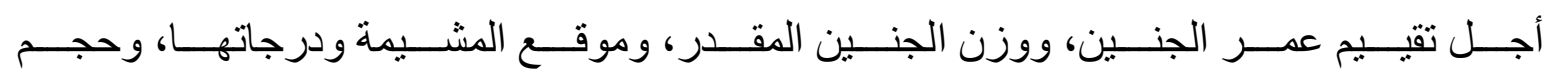


ROLE OF MIDDLE CEREBRAL ARTERY DOPPLER AND AMNIOTIC... 961

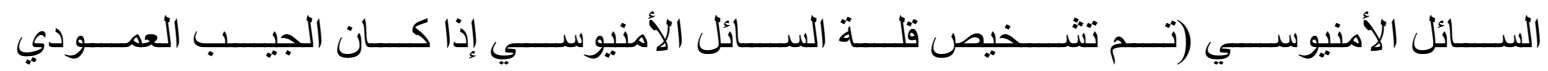

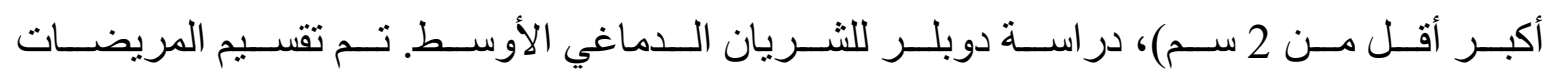

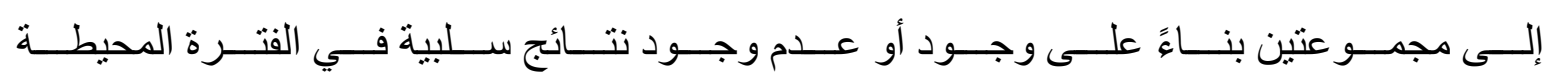
بالو لادة.

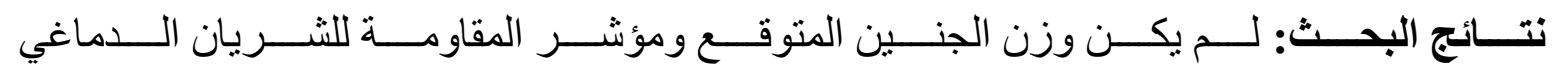

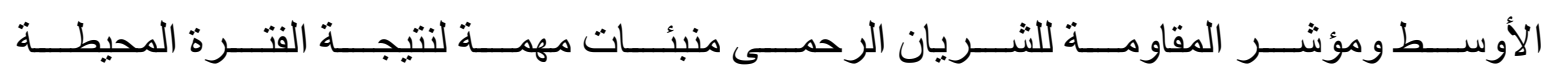

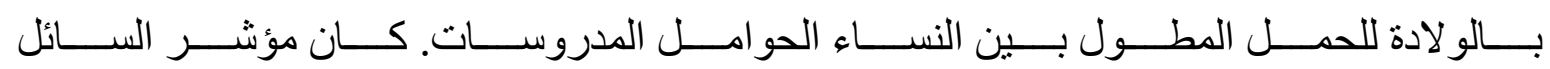

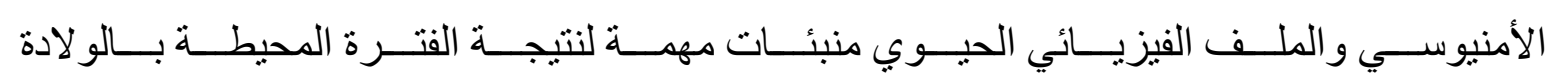
للحمل المطول.

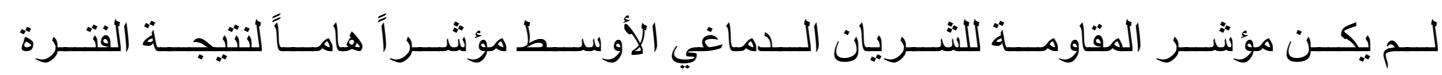

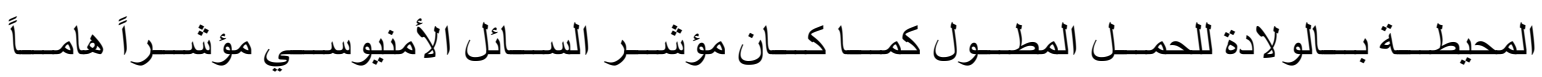
لنتيجة الفترة المحيطة بالو لادة للحمل المطول.

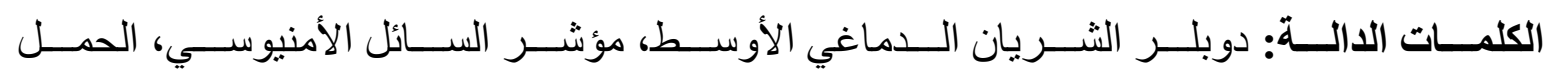
المطول. 